\title{
PERUBAHAN DALAM ORGANISASI PADA IMPLEMENTASI SISTEM INFORMASI
}

\author{
Yosi Agustiawan ${ }^{1}$ \\ ${ }^{1}$ Prodi Sistem Informasi Fakultas Teknik \\ Universitas Pesantren Tinggi Darul 'Ulum (Unipdu) Jombang \\ Kompleks Ponpes Darul 'Ulum Peterongan Jombang 61481 \\ Email : ${ }^{1}$ aghoezt@gmail.com
}

\begin{abstract}
ABSTRAK
Pemanfaatan dan pengembangan sistem informasi yang dapat mengintegrasikan seluruh proses bisnis untuk dapat meningkatkan kinerja perusahaan banyak dilakukan melalui proyek pengadaan paket software atau hardware yang siap pakai di pasaran dan langsung mengimplementasikannya. Implementasi sistem informasi akan melibatkan semua aktivitas organisasi yang berhubungan dengan penggunaan dan manajemen dari sistem informasi tersebut sehingga menyebabkan perubahan proses bisnis. Perubahaan organisasi yang tidak dikelola dengan baik menjadi penyebab utama kegagalan proyek sistem informasi. Manajemen perubahan yang didukung oleh puncak manjeman dan memiliki kemampuan dalam penguasaan teknologi, pengetahuan proses bisnis dan budaya organisasi perusahaan menjadi kunci keberhasilan proyek implementasi sistem informasi.
\end{abstract}

Kata kunci: implementasi, perubahan organisasi, manajemen perubahan

\begin{abstract}
Most of information system development that can integrate all business process in order to improve company performance conducted by purchasing software/hardware package and implement it. Information system implemetation will involve all organizational activities that cause changes in business processes. Organizational change is not managed properly cause the failure of information systems projects. Change management requires top management support and must have the capability of information technology, business processes and organizational culture.
\end{abstract}

Key words: implementation, organizational change, change management

\section{Pendahuluan}

Penggunaan sistem informasi membuat berbagai pekerjaan menjadi lebih terintegrasi, tidak tergantung tempat dan waktu serta dapat menyajikan informasi secara terpusat dan real time. Hal ini sangat bermanfaaat untuk kelancaran informasi, meningkatkan koordinasi dan efisiensi kerja. Besarnya manfaat tersebut membuat banyak perusahaan ingin mengimplementasikan dalam proses bisnisnya dan bahkan banyak diantaranya sudah pada tahap mengembangkan sistem informasi di perusahaannya.

Proses pemanfaatan sistem informasi ini dilakukan melalui beberapa proyek baik sekala kecil, menengah maupun besar. Proyek-proyek tersebut dilihat dari dari karakteristik pekerjaannya menurut Eko Indrajit (2000) dapat dibagi menjadi empat jenis, yaitu:

a. Proyek pembangunan prasarana berupa; jaringan kabel atau wireless dan data center (infrastructure development)

b. Proyek pengadaan paket software atau hardware yang siap pakai di pasaran dan langsung mengimplementasikannya (package implementation).

c. Proyek pembuatan software sendiri berdasarkan kebutuhan yang didesain dan dikerjakan oleh tim sendiri ataupun oleh pihak ketiga (custom development atau in-house development)

d. Melakukan dua atau ketiga hal diatas dan mengintegrasikannya (system integration).

Pada pelaksanaanya proyek sistem informasi biasanya mengadopsi sistem pengembangan pada siklus hidup pengembangan sistem informasi yang dikenal dengan SDLC (sytem development life cycle). Tahapan SDLC sendiri terdiri dari 6 tahap seperti terlihat pada gambar 1.

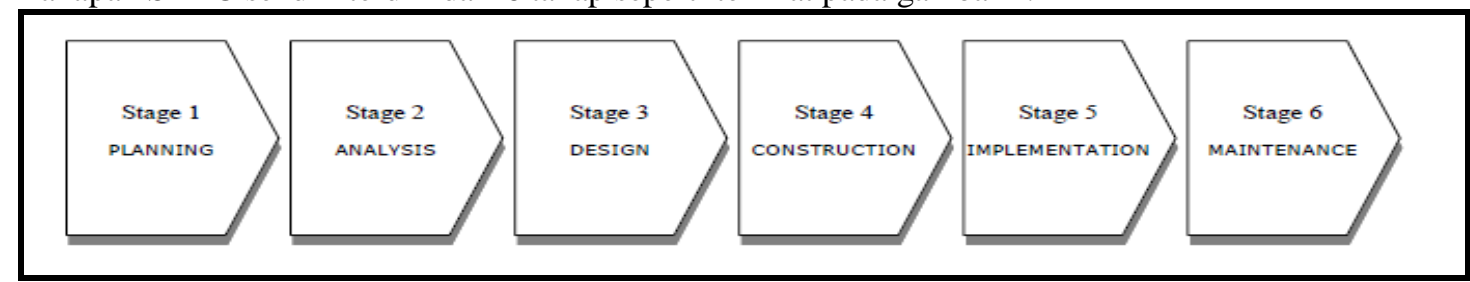

Gambar 1. Sytem Development Life Cycle (Indrajit, 2000) 
Proyek pemanfaatan dan pengembangan sistem informasi bukanlah pekerjaan yang sederhana. Dibutuhkan banyak pihak yang terlibat karena akan banyak mempengaruhi prosesi bisnis dan lingkungan kerja organisasi serta kebanyakan dari pekerjaan tersebut adalah kegiatan investasi yang membutuhkan dana yang besar.

\section{Perkembangan Sistem Informasi}

Mempertimbangkan kompleksitas pekerjaan, besarnya investasi yang diperlukan dan juga besarnya resiko kegagalan maka diperlukan strategi yang tepat agar pemanfaatan dan pengembangan sistem informasi dapat digunakan sesuai dengan harapan. Salah satu cara yang dipilih oleh banyak perusahaan baik besar dan terutama perusahaan kecil seperti UKM (Usaha Kecil Menengah) adalah memilih proyek pengadaan paket software atau hardware yang siap pakai di pasaran dan langsung mengimplementasikannya (package implementation).

Strategi tersebut dipilih dengan pertimbangan dapat lebih cepat diimplementasikan karena tidak membutuhkan waktu untuk membuatnya. Pertimbangan biaya juga menjadi dasar karena paket program dianggap sebagai produk masal sehingga harganya dapat lebih murah. Hal lain yang mendorong penggunaan strategi tersebut adalah semakin banyaknya perusahaan-perusahaan yang telah meningkat kinerjanya berkat menerapkan paket software ERP (Enterprise Resource Planning) dalam sistem informasinya.

Paket software ERP ini banyak terdapat di pasaran dan siap pakai. Beberapa produk ERP yang sering digunakan adalah produk dari SAP dan Oracle. Meskipun awalnya produk ini banyak digunakan oleh perusahaan besar namun saat ini banyak juga UKM yang mengadopsi produk ini karena baik SAP maupun Oracle mengeluarkan juga produk yang dikenal sebagai product for small medium enterprise. Beberapa perusahan yang bergerak dalam pembuatan sistem informasi saat ini juga membuat produk ERP, bahkan tersedia juga software ERP yang bersifat open source.

Banyaknya software ERP di pasaran membuat perusahaan harus jeli untuk memilih sesuai dengan lingkungan organisasinya. Kesalahan dalam memilih akan merugikan perusahaan, mengingat ERP yang berhasil digunakan oleh perusahaan lain bukan berarti dapat sesuai dan menjamin berhasil diterapkan di perusahaannya.

Arti ERP sediri menurut Holy \& Santika (2005) adalah sistem informasi yang saling terintegrasi diantara beberapa area bisnis yang berlandaskan satu source database untuk mengidentifikasikan, mengolah sumber data yang ada, merencanakan dan membantu pengambil keputusan guna memenuhi kebutuhan pelanggan.

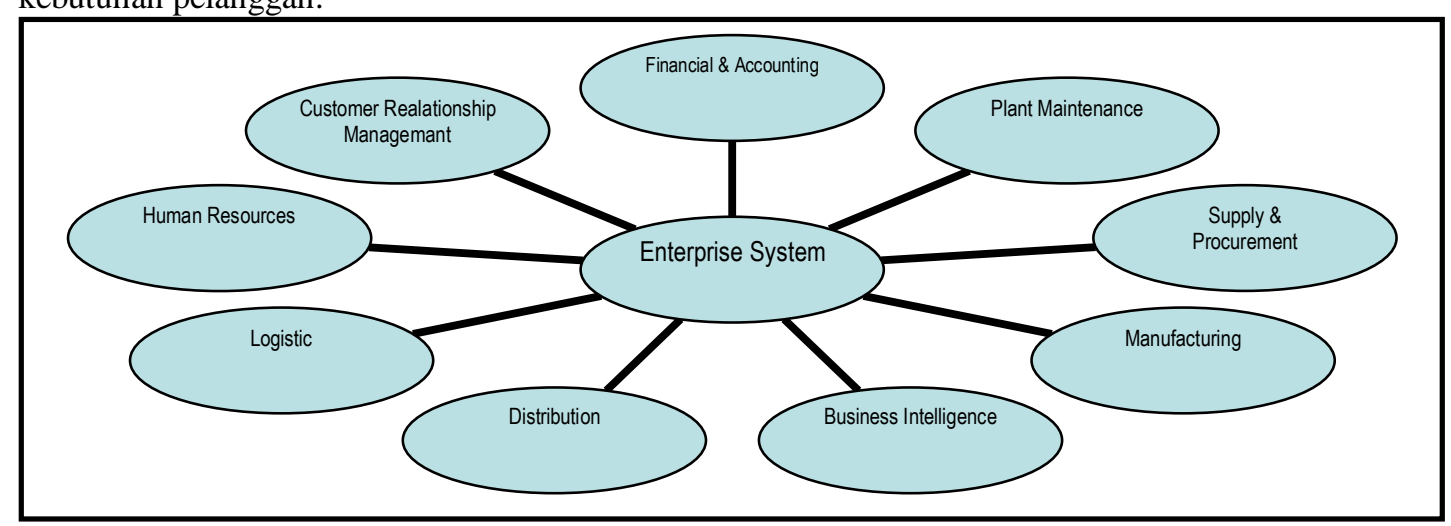

Gambar 2. Konsep Sistem ERP (Holy \& Santika, 2005)

Dengan menggunakan ERP maka seluruh proses bisnis perusahaan dapat terintegrasi dari hulu sampai hilir, sehingga beberapa keuntungan dapat diraih oleh perusahaan diantaranya:

- Menekan biaya pembukuan akunting

- Mengurangi kesalahan didalam koordinasi

- Meningkatkan proses pelayanan

- Membantu mengambil keputusan bagi manajemen

- Menekan biaya transportasi 


\section{Kegagalan Proyek Sistem Informasi}

Pada pelaksanaanya proyek sistem informasi menghadapi kemungkinan untuk berhasil maupun gagal. Tingkat resiko kegagalan menurut Kenneth \& Jane (2007) tergantung dari :

- Ukuran proyek, dimana semakin besar biaya, waktu, organisai dan jumlah staff semakin besar resiko kegagalan proyek.

- Struktur proyek, dimana adanya strutur proyek yang baik dengan kebutuhan yang jelas dan tegas akan mengurangi kegagalan suatu proyek.

- Pengalaman dengan teknologi, dimana kurangnya keahlian dan pengalaman dari anggota proyek terhadap penggunaan teknologi akan meningkatkan resiko kegagalan proyek.

Dari hasil riset ternyata didapat banyak proyek sistem informasi mengalami kegagalan. Riset yang dilakukan oleh Stadish Group pada tahun 2009 memperlihatkan bahwa hanya $32 \%$ proyek yang berhasil, 24\% dibatalkan dan selebihnya $44 \%$ mengalami keterlambatan, pembengkakan biaya ataupun ketidaksesuaian. Data tersebut diperoleh di Amerika sedangkan di Indonesia sendiri menurut majalah SWA pada tahun 2003, $75 \%$ proyek teknologi informasi telah gagal.

Banyak faktor yang menyebabkan kegagalan proyek teknologi informasi, menurut Shauchenka (2012), data dari berbagai lembaga riset menyatakan sebab-sebab kegagalan adalah sebagai berikut:

a. Chaos Report (1995)

- Kebutuhan yang tidak terpenuhi

- Kurangnya keterlibatan dari pengguna

- Kurangnya sumber daya

b. OASIG Study (1995)

- Kurangnya perhatian pada aspek manusia dan organisasi itu

- Lemahnya managemen proyek

- Kurangnya artikulasi kebutuhan penggunan

c. KPMG Canada Survey (1997)

- Kurangnya perencanaan

- Lemahnya pelaksanan

- Kurangnya dukungan dan keterlibatan dari pimpinan

d. The Bull Survey (1998)

- Putusnya komunikasi

- Kurangnya perencanaan

- Kurangnya koordinasi

- Lemahnya pengawasan

e. Coverdale Organization research (Cushing, 2002)

- Lemahnya perencanaan

- Tidak jelasnya tujuan dan sasaran

- Kurangnya dukungan eksekutif dan keterlibatan pengguna

Berdasarkan beberapa hasil riset tersebut dapat disimpulkan bahwa meskipun faktor teknis misalnya berupa kecanggihan teknologi adalah merupakan termasuk faktor kegagalan namun faktor penyebab utama kegagalan justru terletak pada lingkungan internal organisasi. Lingkungan internal organisasi tersebut yaitu; sumber daya manusia berupa kemampuan menguasai teknologi; manajemen berupa kurangnya perencanaan, pelaksanaan dan pengawasan maupun prilaku dalam berorganisasi berupa komunikasi dan koordinasi.

\section{Perubahan Organisasi}

Penggunaan sistem informasi terutama jika perusahaan memutuskan memilih strategi pengembangan sistem informasi dengan melakukan pembelian paket program berkonsekuensi untuk melakukan penyesuaian terhadap sistem informasi yang telah dipilih. Hal ini karena sistem informasi akan merubah cara kerja, keahlian dan manajemen yang akan mempengaruhi proses bisnis dan organisasinya secara keseluruhan sehingga diperlukan suatu perubahan dalam organisasi.

Konsekuensi untuk memilih paket program dalam penggunaan dan pemanfaatan sistem informasi membuat tahap implementasi menjadi tahap yang paling menentukan. Implementasi disini adalah berupa semua aktivitas organisasi yang berhubungan dengan penggunaan dan manajemen dari sistem informasi tersebut. Ada beberapa cara dalam melakukan implementasi sistem, menurut Hanif (2007) : 
a. Cut Over. Sistem lama dihapus dan digantikan dengan sistem baru. Kelebihan cara ini adalah biaya yang lebih murah sedangkan kelemahannya adalah besarnya resiko kegagalan.

b. Paralel Conversion. Sistem lama maupun sistem baru diimplementasikan bersama-sama selama beberapa periode waktu. Secara bertahap sistem lama dapat digantikan oleh sistem baru. Kelebihan cara ini adalah kecilnya resiko kegagalan sedangkan kelemahannya adalah besarnya biaya yang disebabkan berjalannya dua sistem dan juga menjalankan dua sistem dalam satu sistem komputer membuat sistem komputer berjalan lebih lambat.

c. Location Conversion. Ketika beberapa sistem yang sama akan dioperasikan pada lokasi yang berbeda. Konversi biasanya dilakukan pada satu lokasi terlebih dahulu (bisa konversi langsung atau paralel) Ketika sistem pada lokasi tersebut berjalan dengan baik, maka sistem dapat di deploy ke lokasi lainnya. Pada Lokasi pertama disarankan digunakan konversi paralel dan pada lokasilokasi berikutnya bisa dilakukan komversi secara langsung. Kelebihan cara ini adalah dapat mengevaluasi sistem baru sedangkan kelemahannya adalah adanya kerumitan dalam pelaksanaannya.

d. Stage conversion. Seperti location conversion merupakan variasi dari konversi langsung dan konversi paralel. Suatu sistem dikembangkan dengan versi awal kemudian diimplementasikan bisa dengan paralel atau langsung. Kemudian versi berikutnya diimplementasikan lagi, sampai versi yang sesuai dengan kebutuhan organisasi atau perusahaan.Kelebihan cara ini adalah kecilnya resiko kegagalan sedangkan kelemahannya adalah membutuhkan waktu lebih lama.

Pemilihan terhadap cara tersebut tergantung pertimbangan masing-masing perusahaan, melihat masingmasing cara memiliki kelebihan dan kekurangan. Masing-masing cara implementasi tersebut juga memiliki pengaruh langsung pada perubahan proses bisnis dan organisasi perusahaan sehingga diperlukan analisis yang mendalam agar tidak mengganggu atau bahkan menghentikan aktivitas proses bisnis.

Perubahan dalam organiasasi yang disebabkan oleh penggunaan sistem informasi menurut Kenneth \& Jane (2007) adalah otomatisasi dan rasionaliasasi, rekayasa ulang dan perubahan paradigma. Otomatisasi adalah bentuk umum awal perubahan organisasi yang berupa alat bantu bagi kemudahan pekerjaan sehari-hari. Adanya otomatisasi membuat pemangkasan prosedur-prosedur sehingga rasionalisasi prosedur adalah perubahan yang mengikuti otomatisasi. Rekayasa ulang atau lebih dikenal dengan business process reengineering adalah adalah perubahan radikal yang dilakukan pada organisasi dengan melakukan analisa dan perancangan ulang sehingga dapat berakibat pada perubahan paradigma.

Sistem informasi berperan penting dan menjadi faktor pendorong bagi perusahaan untuk menata ulang aliran-aliran kerja, menggabungkan langkah-langkah untuk mengurangi tugas-tugas yang berulang atau bahkan mengurangi beberapa bagian pekerjaan. Proses re-engineering tanpa menggunakan sistem informasi tidak akan dapat berhasil dengan baik.

Setiap perubahan karena penggunaan sistem informasi membawa keuntungan dan resiko yang berbedabeda. Perubahan dalam bentuk otomatisasi dan rasionalisasi relatif berjalan lamban dan keuntungan yang didapat tidak terlalu besar, namun memiliki tingkat resiko yang kecil. Sebaliknya rekayasa ulang dan perubahan paradigma membuat perubahan menjadi lebih cepat dan menyeluruh sehingga mendapatkan keuntungan yang tinggi namun juga memiliki resiko yang cukup besar.

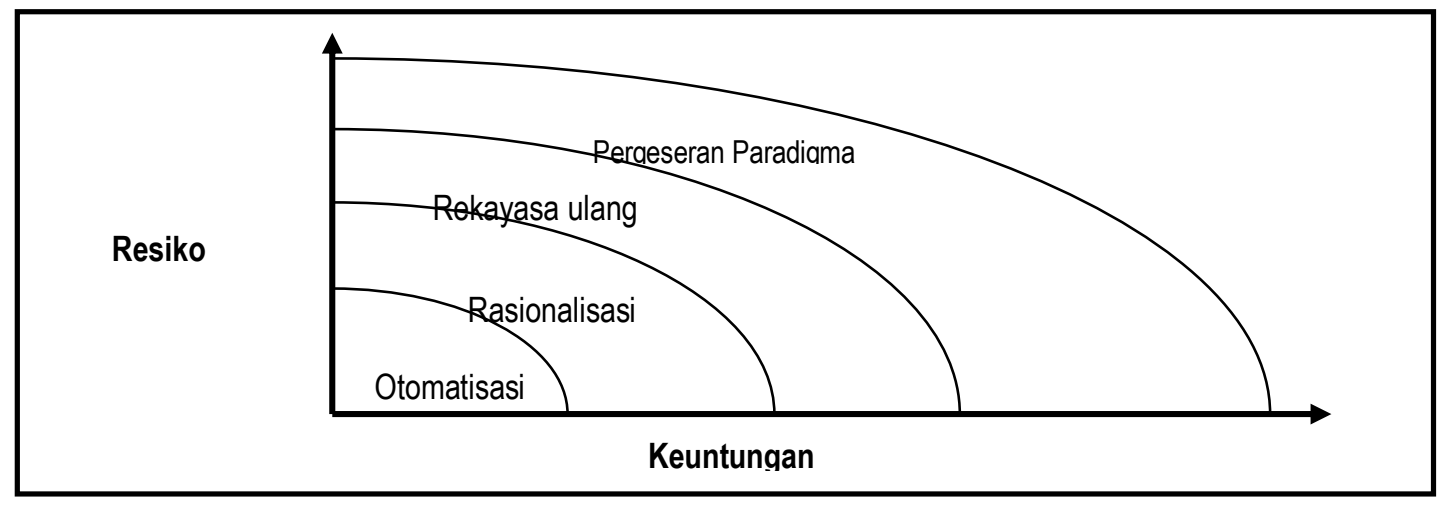

Gambar 3. Keuntungan dan Resiko Perubahan Organisasi (Kenneth \& Jane, 2007) 


\section{Manajemen Perubahan Organisasi}

Melakukan perubahan dalam organisasi bukanlah pekerjaan yang mudah terutama pada perusahaan yang sudah besar. Diperlukan suatu pengelolaan melalui langkah-langkah yang terencana agar menghasilkan suatu perubahan sesuai dengan yang diharapkan.

Kasali (2005) mengungkapkan teori force field dari Kurt Lewin yang menyimpulkan bahwa daya dorong perubahan (driving forces) akan berhadapan dengan penolakan (resistences) untuk berubah. Untuk melakukan perubahan maka daya dorong perlu ditingkatkan dan dilakukan terus menerus agar dapat melemahkan penolakan dan pada gilirannya akan menghilangkan penolakan. Jika penolakan sudah hilang maka perubahan tersebut dapat dibakukan menjadi sebuah sistem baru. Langkah-langkah untuk melakukan hal tersebut adalah:

a. Unfreezing yaitu suatu upaya penyadaran perlunya suatu perubahan.

b. Changing yaitu suatu upaya berupa tindakan untuk memperkuat daya dorong atau untuk memperlemah penolakan.

c. Refreezing yaitu upaya agar keseimbangan yang baru terbentuk (a new dynamic equilbrium) dibakukan agar dapat bertahan lama.

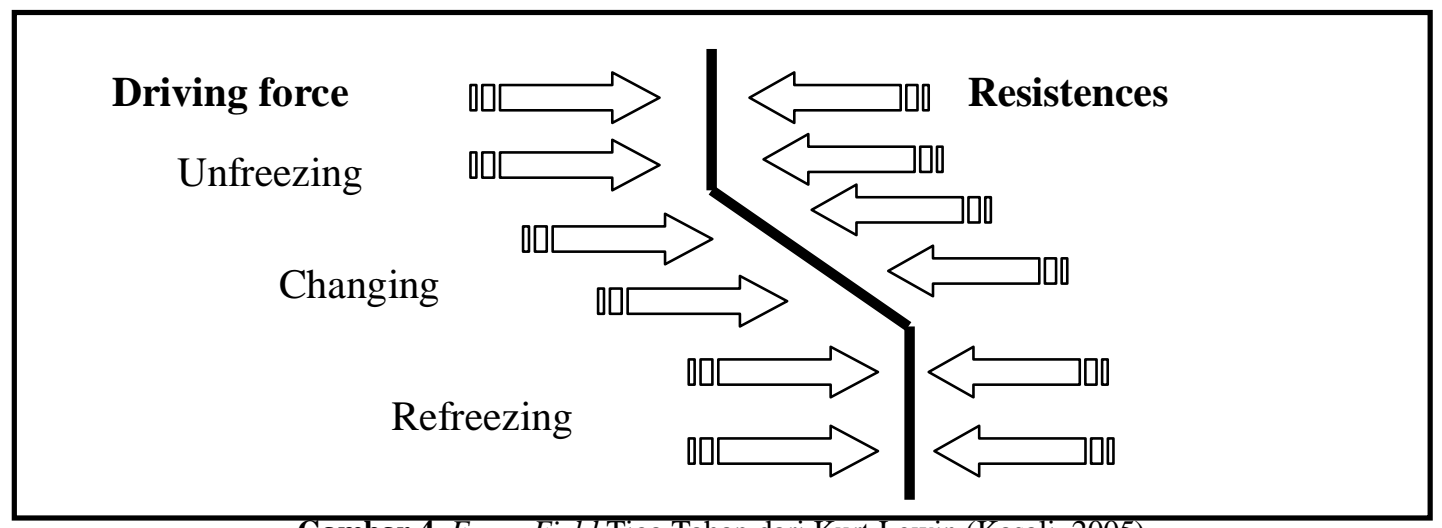

Gambar 4. Force Field Tiga Tahap dari Kurt Lewin (Kasali, 2005)

Permasalahan utama dalam melakukan perubahan organisasi adalah resistance of chance terutama berupa kebiasaan yang sudah lama melekat sehingga sulit untuk ditinggalkan. Menurut Stephen Robbins \& Timothy (2008) resistensi terhadapa perubahan dapat bersumber pada:

a. Sumber-sumber individual yang ada dalam karateristik manusia sendiri seperti persepsi, kepribadian dan kebutuhan. Hal ini berupa rasa aman, faktor-faktor ekonomi, ketakutan pada hal yang belum diketahui dan pemrosesan informasi yang selektif.

b. Sumber-sumber organisasional terletak pada susunan struktural organisasi itu sendiri. Hal ini berupa Inersia struktural, fokus perubahan yang terbatas, inersia kelompok, ancaman terhadap keahlian, ancaman terhadap relasi kuasa yang sudah mapan, dan ancaman terhadap pengalokasian sumber daya yang sudah mapan.

Resistensi tersebut dapat terlihat secara langsung atau terbuka misalnya berupa keluhan, memperlambat kerja sampai kepada mogok kerja karyawan. Resistensi jenis ini dapat segera dicari sumber penyebabnya dan dicarikan alternatif solusinya. Sedangkan resistensi yang tidak terlihat secara langsung atau implisit misalnya turunnya motivasi, loyalitas, dan kinerja karyawan lebih sulit untuk dicari sumber penyebabnya sehingga lebih sulit juga untuk dicarikan alternatif solusinya.

Kotter \& Schlesinger (1997) dalam Kasali (2005) menyatakan bahwa diperlukan enam strategi untuk mengatasi resisitensi dalam perubahan yaitu komunikasi, partisipasi, fasilitasi, negosiasi, manipulasi, dan paksaan. Teknik yang berbeda-beda diperlukan untuk penerapannya pada kelompok-kelompok yang berbeda dan tergantung pada tingkat resistensinya. Langkah-langkah digambarkan pada gambar 4 yang menunjukan strategi untuk mengatasi resistensi, dimana semakin kekanan semakin sulit untuk mengatas resistensinya. 


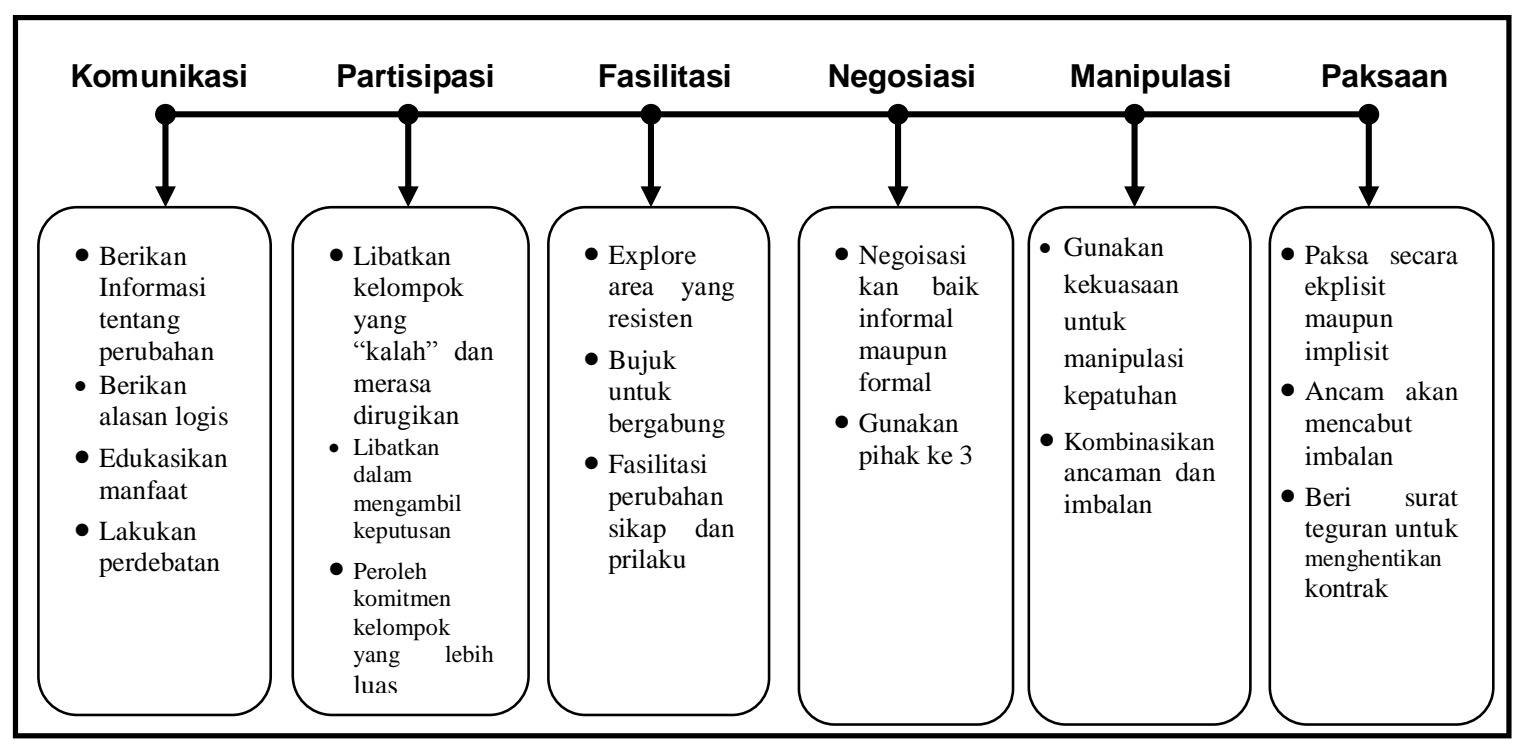

Gambar 5. Pendekatan untuk Mengatasi Resistensi dari Kotter \& Schlesinger (Kasali, 2005)

Perubahan yang disebabkan karena adanya implementasi sistem informasi perlu dilakukan dengan cara membentuk tim implementasi proyek sistem informasi. Tim ini bertanggung jawab pada proses penggunaan dan adopsi sistem informasi oleh pengguna didalam perusahaan sehingga tim ini harus memiliki kemampuan penggunaan teknologi, pengetahuan proses bisnis dan budaya organisasi perusahaan. Dukungan dan komitmen dari manajemen puncak dan pengguna (user) seperti yang dikemukakan oleh Bradford \& Florin (2003) dalam Tarigan (2007) diperlukan agar tim ini dapat bekerja dengan baik.

\section{Penutup}

Perubahan proses bisnis yang dipengaruhi oleh perkembangan teknologi menuntut perusahaan untuk melakukan adaptasi. Proses adaptasi berupa pemanfaatan sistem informasi mutlak diperlukan agar dapat bersaing sehingga dapat bertahan dan terus berkembang. Efek dari pemanfaatan sistem informasi adalah adanya perubahan-perubahan pada organisasi.

Adanya kenyataan bahwa sebagian proyek sistem informasi mengalami kendala karena proses perubahan organisasi tidak ditangani dengan baik, maka perusahaan perlu menyiapkan secara matang. Persiapan tersebut harus melalui suatu perencanaan yang terukur dan memiliki tujuan yang jelas dengan melibatkan berbagai pihak yang terkait baik direksi, manajer maupun karyawan untuk melakukan perubahan yang konfrehensif.

Manajemen perubahan sangat diperlukan agar perubahan yang direncanakan dapat berhasil dengan baik dan tidak sebaliknya bahwa perubahan justru akan menghancurkan perusahaan. Diperlukan agen perubahan (change agent) yang kuat yang didukung oleh manajemen puncak untuk dapat menjalankan manajeman perubahan ini. Peran ini dapat dilakukan oleh anggota internal organisasi sendiri atau diambil dari luar organisasi seperti menggunakan konsultan.

Agen perubahan harus dapat menjembatani berbagai kepentingan dalam perubahan organiasisi melalui berbagai tahapan dan cara yang berbeda-beda untuk berbagai kasus. Pemberian pelatihan atau training harus diberikan kepada semua pihak yang terlibat sebelum dan selama tahap implementasi berlangsung. Melalui pemberian pelatihan yang dilakukan dengan komunikasi yang baik maka dapat ditumbuhkan partisipasi yang pada gilirannya dapat menumbuhkan rasa memiliki (sense of ownership) terhadap sistem baru yang akan diterapkan sehingga seluruh jajaran pengguna atau SDM akan dengan mudah menerima sistem tersebut dan memeliharanya di masa-masa mendatang dengan baik.

Evaluasi melalui diskusi perlu difasilitasi secara berkala untuk menilai kinerja sistem baru yang diterapkan. Hal ini berguna untuk mengetahui isu-isu permasalahan yang timbul sehingga pemecahan masalah dalam tahap implementasi dapat segera dicari solusinya melalui pendekatan-pendekatan baik teknis maupun persuasif sehingga sistem tersebut dapat efektif penggunaannya. 


\section{Daftar Pustaka}

Gaol, J. L., 2008. Sistem Informasi Manajemen pemahaman dan aplikasi. Grasindo: Jakarta.

Indrajit, E. R., 2000. Pengantar Konsep Dasar Manajemen Sistem Informasi dan Teknologi Informasi. Elex Media Komputindo: Jakarta.

Fatta, H. A., 2007. Analisis dan Perancangan Sistem Informasi untuk Keunggulan Bersaing dan Organisasi Modern. Andi Offset: Yogyakarta.

Laudon, K. C., dan Laudon, J. P., 2007. Sistem Informasi Manajemen Mengelola Perusahaan Digital Buku 2 Edisi 10. Salemba Empat: Jakarta.

Kasali, R., 2005. Change. Gramedia: Jakarta.

Robbins, S. P., dan Judge, T. A., 2008. Prilaku organisasi Buku 2. Salemba Empat: Jakarta.

Tarigan, Z., 2007. Pengaruh Key User Terhadap Kinerja Perusahaan Pada Implementasi Teknologi ERP. Universitas Petra: Surabaya.

Yunarto, H. I., dan Santika, M. G., 2005. Bussines Concepts Inplementation series in Inventory Management. Elex Media Komputindo: Jakarta.

Stadish group, 2009. CHAOS Summary, 2009. Tersedia: http://www1.standishgroup.com/newsroom/ chaos_2009.php. Diakses Februari, 2012.

Shauchenka, U., Why Projects Fail. Tersedia: http://whyprojectfailbook.com. Diakses Februari, 2012. 